\title{
Preliminary validation of the paediatric vasculitis activity score (PVAS)
}

\author{
Fiona E Price-Kuehne ${ }^{1}$, Despina Eleftheriou', Seza Ozen², Michael Beresford ${ }^{3}$, Pavla Dolezalova ${ }^{4}$, Paul A Brogan $^{1 *}$ \\ From 18th Pediatric Rheumatology European Society (PReS) Congress \\ Bruges, Belgium. 14-18 September 2011
}

\section{Background}

There is a paucity of evidence-based data for the treatment of primary systemic vasculitis (PSV) in childhood, partly due to the lack of a standardised outcome-measure for use in clinical trials. The Paediatric Vasculitis Activity Score (PVAS) is a quantitative clinical-index of manifestations of active disease, divided into 9 organ sub-systems.

\section{Objective}

To provide preliminary validation of the PVAS.

\section{Methods}

Children at Great Ormond Street Hospital NHS Trust with a diagnosis of PSV underwent simultaneous assessment of disease activity by 2 assessors. Scores were assessed for inter-observer variability and correlation with the physician's global assessment of disease activity (PGA), ESR and CRP. Patients with newly diagnosed PSV were assessed twice: at diagnosis and 1 month, to assess tool-responsiveness to a change in disease state.

\section{Results}

23 children with PSV were studied - 48\% male, 52\% female. The diagnoses were: Behçet's disease $(n=7)$, Wegener's granulomatosis $(\mathrm{n}=5)$, polyarteritis nodosa $(n=5)$, cutaneous leukocytoclastic vasculitis $(n=3)$, Cogan's syndrome $(\mathrm{n}=1)$, microscopic polyangiitis $(\mathrm{n}=1)$ and unclassified vasculitis $(\mathrm{n}=1)$. Median PVAS was 1.5 (range 0-38). Bland-Altman analysis demonstrated high inter-observer agreement and Kappa analysis showed perfect agreement for $8 / 9$ organ-system scores $(K=1$, $\mathrm{p}=0.00)$. Spearman's rank showed correlation between PVAS and PGA $\left(r_{s}=0.87,95 \% \mathrm{CI}=0.71\right.$ to $\left.0.94, \mathrm{p}=0.00\right)$

${ }^{1}$ Dept of Rheumatology, Institute of Child Health and Great Ormond Street Hospital, London, UK

Full list of author information is available at the end of the article and CRP $\left(r_{s}=0.54,95 \% \mathrm{CI}=0.10\right.$ to $\left.0.81, \mathrm{p}=0.02\right)$ but no correlation with ESR $\left(r_{s}=-0.1\right)$. Four newly diagnosed patients demonstrated a fall in the PVAS in response to therapy (change in median from 13.5/63 to 3.5/63), with good agreement for this change between assessors.

\section{Conclusion}

This study provides preliminary evidence that PVAS is a useful clinical measure of vasculitis disease-activity with good inter-observer reliability and correlates highly with the PGA and CRP.

\section{Author details}

${ }^{1}$ Dept of Rheumatology, Institute of Child Health and Great Ormond Street Hospital, London, UK. ${ }^{2}$ Hacettepe University Hospital, Ankara, Turkey. ${ }^{3}$ Alder Hey Children's Hospital, and University of Liverpool, UK. ${ }^{4}$ Charles University $1^{\text {st }}$ Medical Faculty, Prague, Czech Republic.

Published: 14 September 2011

doi:10.1186/1546-0096-9-S1-015

Cite this article as: Price-Kuehne et al.: Preliminary validation of the paediatric vasculitis activity score (PVAS). Pediatric Rheumatology 20119 (Suppl 1):015.

Submit your next manuscript to BioMed Central and take full advantage of:

- Convenient online submission

- Thorough peer review

- No space constraints or color figure charges

- Immediate publication on acceptance

- Inclusion in PubMed, CAS, Scopus and Google Scholar

- Research which is freely available for redistribution

\section{Ciomed Central}

